UDK: 577.2: 633.34

\title{
POLYMORPHISMS IN SSR-LOCI ASSOCIATED WITH E GENES IN SOYBEAN MUTANT LINES OFFER PERSPECTIVE FOR BREEDING
}

\author{
D. O. Zharikova ${ }^{1}$, G. O. Chebotar ${ }^{1}$, E. A. Aksyonova ${ }^{2}$, \\ I. V. Temchenko ${ }^{3}$, S. V. Chebotar ${ }^{1 *}$ \\ ${ }^{1}$ Department of Genetics and Molecular Biology, Odessa I.I. Mechnikov National University, Odessa, Ukraine \\ ${ }^{2}$ Lab. of Cytoplasmic Inheritance, Institute of Genetics and Cytology, Minsk, Belarus \\ ${ }^{3}$ Institute of Feeds and Agriculture of Podillia of NAAS, Vinnitsa, Ukraine \\ E-mail:s.v.chebotar@onu.edu.ua*,gchebotar@gmail.com,fri@mail.vinnica.ua, \\ axenova_elena@mail.ru,daria.bigen14@gmail.com
}

Received August 05, 2019 / Received October 03, 2019 / Accepted November 19, 2019

\begin{abstract}
Aim. To analyse genetic diversity in 10 new soybean lines created by using the chemical mutagens D-6, DMSSO-11, DMSSO-12, DMSNPIR-11, DUDMS12, D12DMC-11B obtained from four cultivars Femida, Oksana, Podils'ka 416, Zolotysta. The microsatellite (MS) markers Satt100, Satt229, Satt319, Satt354, Satt365, Sat_038 were used. These markers are linked with genes, which determine sensitivity of soybean plants to photoperiod and time to maturation. Methods of DNA extraction, PCR, MS-analysis, field trial, one-way analysis of variance (ANOVA) have been applied. Results. Parental cultivars, mutant lines and control genotypes were characterized by alleles of microsatellite loci, 25 alleles of 6 microsatellite loci were detected. Significant differences between investigated lines were detected in three year field trials for traits - days to maturation (DTM) and length of the vegetative period (LV). We have revealed effects of the factor «Alleles of MS-locus», so alleles of Satt100 locus affected all traits except DTF (days to flowering); alleles of Satt319 and Satt354 affected DTM and LV; Sat_038 affected DTF and S-F (duration of the period shoots-flowering). Lines with alleles 167 bp at Satt100 and 175 bp at Satt319 loci (that marks dominant E7) were shown to have a longer vegetation period and later maturity, than other. The lines with allele 247 bp at Sat_038 flowered earlier, than lines with a $245 \mathrm{bp}$ allele, and the lines with allele $232 \mathrm{bp}$ at Satt354 reached maturity later, than lines with other alleles at this locus. Conclusions. We have found that applied mutagens induce changes in the soybean genome and by using these mutagens it is possible to effectively increase genetic diversity in loci associated with genes/loci that determine time of maturity and/or photoperiod sensitivity of soybean, enabling to obtain soybean cultivars with different terms of maturity and yield. The microsatellite markers, particularly Sat_038, Satt100, Satt319 and Satt354 that were applied in our study are considered to be useful tools for marker assisted breeding of soybean cultivars with programmed time of development. We did not observe significant effects of «Alleles of MS-locus Satt229» that is known to be linked with $E 3$ on the investigated agronomical traits. For soybean genotypes with the $E 7$ allele the DTF was longer for 3-9 days and LV for 10-11 days. In lines with an allele of 175 bp at locus Satt319 the S-F period was 6-9 days shorter.
\end{abstract}

Keywords: soybean, mutant lines, polymorphism, SSR-loci, microsatellite markers, $E$ genes, photoperiod, maturity.

DOI:

\section{INTRODUCTION}

Flowering time is critical for successful seed production of plants, and with time to maturity it determines geographic adaptation, seed quality and yield. In con-

(C) D. O. ZHARIKOVA, G. O. CHEBOTAR, E. A. AKSYONOVA, I. V. TEMCHENKO, S. V. CHEBOTAR, 2019 trast to most cereals, soybean (Glycine $\max (\mathrm{L}$.$) Merr.)$ cultivars are confined to comparatively narrow ranges of geographical latitudes [1]. For each degree of changes in latitude (corresponding to $100-150 \mathrm{~km}$ ), it is better to develop a new (better adapted to environmental conditions) cultivar [2]. 
Across the world, cultivars of soybean can grow in a wide range of latitudes from $55^{\circ} \mathrm{N}$ to $35^{\circ} \mathrm{S}[3,4]$. Northern than $55^{\circ} \mathrm{N}$ latitude most genotypes do not mature [4]. In Ukraine breeders identify the area most favorable for growing this crop, the so-called «Soybean's Belt», which is located on irrigated soils and is between $46^{\circ} \mathrm{N}$ and $51^{\circ} \mathrm{N}$. According to [4] in 5 regions of the Forest-Steppe Zone: Vinnitsa, Kyiv, Poltava, Cherkasy and Khmelnitsky and Steppe- Kropyvnytsky, more than $60 \%$ of all soybean in Ukraine is grown. For all regions of Ukrainian «Soybean's Belt» extra-early and early maturity groups of soybeans allow to expand the area of this crop considerably, to get dry grain without drying, to use soybean as intermediate and repeated crops are especially important [5].

The development of early-ripeness (short season) soybeans for different regions of Ukraine requires effective use of early maturity genes. Detection of alleles of $E$ genes that are involved in the control of plant response to photoperiod and determination of the days to flowering (DFT) and days to maturation (DTM) with microsatellite markers could help in the evaluation of adaptive capacity of soybean cultivars under different growth conditions [2].

Soybean production in Ukraine increases every year since its wide introduction in 2007, and now Ukraine is one of the leaders in the production of soybean in Europe [6]. There are few investigations of molecular genetic polymorphism in the genome and genes that affect time to flowering (involved in mechanism of photoperiodic sensitivity of plants) with molecular markers for Ukrainian soybean cultivars [7-11]. But optimization of soybean breeding and development of new cultivars with good adaptability to the conditions of Ukraine are important.

Breeders are interested in developing new material with effective alleles of $E$ genes (early maturity genes) for Ukraine $[4,5,12]$. By using experimental mutagenesis, it is possible to get a high level of genetic variability. But it is impossible to predict to which changes chemical mutagenesis will lead to. The mutagenic factors in soybean selection are most often used for production of new forms that differ from the original cultivars according to individual characteristics: seed coloration, plant height, seed size, leaf shape, duration of the vegetative period, content and quality of protein and seed oil, resistance to pathogens and increasing productivity elements, especially: main stem nodes, pods per plant, seeds per plant, weight of thousand seeds [13, 14]. The main aim of modern soybean breeding is improving the productivity, technological qualities of the seeds, increasing resistance to biotic and abiotic factors, yield, fertility, optimizing the growing season [15].

The purpose of our work was to analyze genetic diversity in mutant lines of soybean by using the microsatellite (MS) markers Satt100, Satt229, Satt319, Satt354, Satt365, Sat_038 linked with genes that determine sensitivity of soybean to photoperiod and time to maturation. These markers are recommended for $E 1$, E3, E4 and E7-genes detection by Molnar et al. [16]. The markers Satt100, Satt319, we used as recommended by Rosenzweig et al. [17].

\section{MATERIALS AND METHODS}

A set of new soybean lines created with the help of chemical mutagenesis from cultivars Femida, Oksana, Podils'ka 416, Zolotysta, that belong to different groups of maturation [18-20], was used as a material for investigation.

As mutagens were used: D-6, DMSSO-11, DMSSO12, DMSNPIR-11, DUDMS12 and D12DMC-11B, that are derivatives of tetrahydrothiophene-N-dioxide-3,4-diamine and tetrahydrothiophene-N-dioxide3,4-pyridine, provided by P.G. Dul'nev from V.P. Kukhar Institute of Bioorganic Chemistry and Petrochemistry of the National Academy of Sciences of Ukraine (Kiev, Ukraine).

The mutagens were applied on seeds in aqueous solution at concentrations of $0.05 \mathrm{~g} / 1,0.5 \mathrm{~g} / 1,5 \mathrm{~g} / 1$, and $10 \mathrm{~g} / \mathrm{l}$. Seeds were exposed to the mutagens for 2,4 , 8,16 hours [21]. After mutagenic treatment lines were grown in an experimental field during 5-7 agronomical seasons in the Institute of Feeds and Agriculture of Podillia of NAAS (IFAP; Vinnitsa, Ukraine). Then, mutant lines perspective for breeding with internodes less than $5 \mathrm{~cm}$ were selected in order to reduce the length of internodes, to decrease the vegetative mass of plants and to increase the generative mass of seeds and beans (Dr. S.V. Ivanyuk, personal communication (IFAP)).

DNA was isolated from soybean seeds of $10 \mathrm{mu}-$ tant lines and parental cultivars using the DNA-NeoPrep100 kit (Neogen Laboratory, Kiev, Ukraine). Five randomly chosen seeds from each of the parents and mutant lines were used for DNA isolation. PCR with primers specific for the microsatellite loci Satt100, Satt229, Satt319, Satt354, Satt365, Sat_038 was performed according to the method of Monlar et al. [16]. For fragment analysis and detection of the alleles of MS-loci the ABI PRISM® Genetic Analyzer 
3500 (Applied Biosystems) was used in the Institute of Genetics and Cytology (Minsk, Belarus). The results were analyzed with GeneMapper ${ }^{\circledR}$ Software Version 4.1. As a standard of molecular weight, the Orange DNA size standard (MCLABs http://www. mclab.com/DNA-SizeStandard) was used. As controls for PCR analysis served DNA of accession Harosoy isolanes from OT 89-5 (here in after Harosoy OT 89-5) and DNA of soybean cultivars Vilana, Ros', Cormoran AC, Maple Arrow.

Accession Harosoy OT 89-5 and cultivar Vilana carry of the dominant $E 7$ allele, Maple Arrow - the dominant $E 3$ allele, Cormoran $\mathrm{AC}$ has the dominant $E 1$ allele and Ros' carries the dominant E2 allele [22].

Agronomical traits, such as days to flowering (DTF), days to maturation (DTM), length of the vegetative period (LV - days), duration of the period shoots-flowering (S-F - days) and yield ( $\mathrm{t} / \mathrm{ha}$ ) were investigated in three year trials (2016-2018) under field conditions of IFAP, $49^{\circ} 13^{`} \mathrm{~N}$ (Vinnitsa, Ukraine). Parental cultivars, mutant lines, and the controls, cultivars Vilana and Maple Arrow were sown all at the same day.

Parental cultivars and control isolines belong to different maturity groups: (00 - early maturity (91-110 days)) - Harosoy OT 89-5, Ros', Zolotysta; (0 - middle maturity (111-130 days)) - Maple Arrow, Cormoran AC, Podilska 416; (I - middle late maturity (131-150 days)) - Vilana $[18,23]$. According to the Catalog of varieties of forage and field crops of IFAP, cultivar Femida, which has LV - 116-124 days, belongs to the middle maturity group I and cultivar Oksana, which LV is 125-132 days, belongs to the middle-late maturity group II [24]. So, cultivars in the same group of maturity could have different alleles of $E$-genes. Classification of maturity groups (MGs) for soybean cultivars have been developed in the 1940s, it was revised and improved from these times and now includes 13 MGs $(000,00$, $0, \mathrm{I}-\mathrm{X}$ ), according to Liu et al. [25]. In different countries scientists have adopted this system to local conditions, for example, in Japan local soybeans differentiate in 8 MGs (0-VII), in India local cultivars are mainly in $\mathrm{V}-$ VIII MGs, in Italy soybean cultivars are from 0 to II MGs, in France - from 000 to II MGs. At the same time the system of MGs is a major approach in characterizing ecological properties and possible growing areas of cultivars and lines [25], there is a mind that the difference in maturity date between two adjacent groups is approximately 10 to 15 days in adapted area [25].

Table 1. Allelic characteristic of parental and mutant lines by microsatellite loci

\begin{tabular}{l|c|c|c|c|c|c}
\hline \multirow{2}{*}{$\begin{array}{l}\text { Parental and control } \\
\text { cultivars/mutant lines }\end{array}$} & \multicolumn{7}{|c}{ Microsatellite loci (bp) } & \multicolumn{2}{l}{} \\
\cline { 2 - 6 } & Satt100 & Satt229 & Satt319 & Satt354 & Satt365 & Satt038 \\
\hline Oksana & 167 & 230 & 175 & 232 & 301 & 247 \\
Oksana M2 & $\mathbf{1 4 1}$ & 230 & $\mathbf{1 8 0}$ & 232 & 301 & 247 \\
Oksana M12 & 167 & $\mathbf{2 3 4}$ & 175 & $\mathbf{2 4 9}$ & 301 & $\mathbf{2 4 5}$ \\
Oksana M13 & $\mathbf{1 4 1}$ & $\mathbf{2 3 4}$ & $\mathbf{1 8 0}$ & $\mathbf{2 4 9}$ & 301 & $\mathbf{2 4 5}$ \\
Zolotysta & 141 & 234 & 180 & 178 & 301 & 247 \\
Zolotysta M16 & $\mathbf{1 3 1}$ & $\mathbf{2 3 0}$ & $\mathbf{1 7 8}$ & 178 & $\mathbf{2 7 0}$ & 247 \\
Zolotysta M20 & 141 & $\mathbf{2 3 0}$ & 180 & $\mathbf{2 3 0}$ & 301 & 247 \\
Femida & 110 & 212 & 175 & 230 & 301 & 247 \\
Femida M29 & $\mathbf{1 6 7}$ & 212 & 175 & 178 & 301 & 245 \\
Femida M32 & 113 & 212 & 175 & 230 & 301 & 245 \\
Podils'ka 416 & 110 & 215 & 175 & 230 & 301 & 245 \\
Podils'ka 416 M33 & $\mathbf{1 4 1}$ & $\mathbf{2 3 4}$ & $\mathbf{1 8 0}$ & 230 & 301 & $\mathbf{2 4 7}$ \\
Podils'ka 416 M38 & $\mathbf{1 4 1}$ & $\mathbf{2 3 4}$ & $\mathbf{1 8 0}$ & 230 & 301 & 245 \\
Podils'ka 416 M40 & $\mathbf{1 1 3}$ & $\mathbf{2 1 2}$ & 175 & 230 & 301 & 247 \\
Ros' & 145 & 215 & 178 & 178 & 270 & 243 \\
Vilana & 167 & 234 & 175 & 249 & 301 & 247 \\
Harosoy OT 89-5 & 167 & 183 & 175 & 216 & 301 & 247 \\
Cormoran AC & 131 & 183 & 178 & 178 & 270 & 247 \\
Maple Arrow & 131 & 215 & 178 & 178 & 215 & 247 \\
\end{tabular}



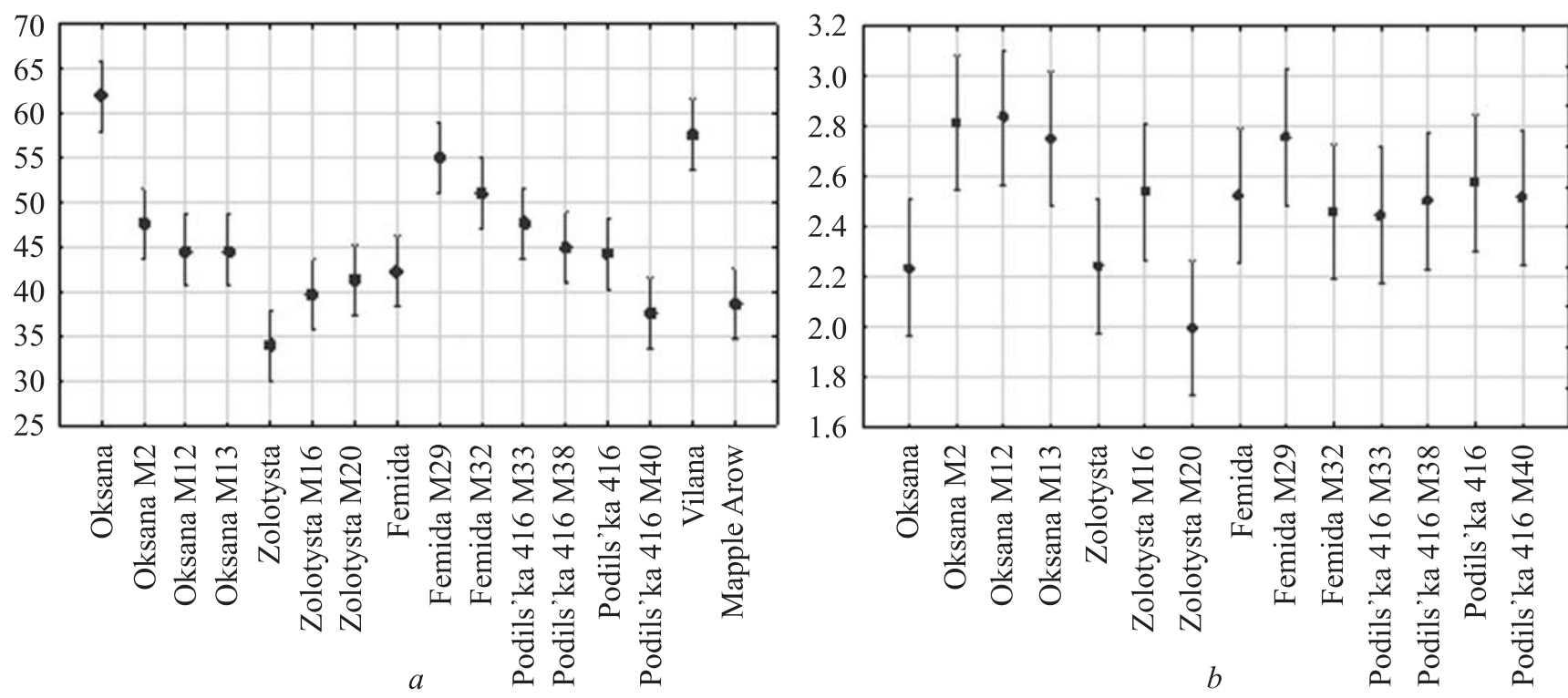

Fig. 1. Mean values \pm std. err. of DTM $(a) \mathbf{y}$ - in days from the beginning of August; $(b)$ yield in $\mathrm{t} / \mathrm{ha}$ of mutant lines and parental cultivars of soybean over a period of three growing seasons (2016 to 2018). Bar $=$ std. err.

We used the one-way analysis of variance (ANOVA) and the Statistica 10 software for analysis of the results of the field experiments. The significance of interline variations for each trait was determined using Fisher's exact test (F-test) and LSD of the corresponding level of significance for the investigated factors.

\section{RESULTS AND DISCUSSION}

In total 25 alleles of 6 MS-loci for the investigated parental, mutant and control genotypes were detected (Table 1). The number of alleles per locus ranged from 3 to 6 with an average of 4.2. In the genotypes of 10 mutant lines, which were selected as promising for breeding, we have revealed new alleles of microsatellite loci that were not present in parental cultivars (bold in the Table 1). The changes of allele size in mutant lines were detected in $52 \%$ of the cases of comparisons with the alleles of the same loci in the parental cultivars.

These changes can be explained by the action of mutagenic substances applied at different concentrations on soybean by inducing instability and mutations in «hot spots» of the genome, among which microsatellite loci can act. We supposed that mutagenic treatment, however, could have influence on generative apparatus of soybean [26], that leads to open flowering and possible pollination by pollen of other cultivars and soybean lines grown adjacent to the experimental field. In general, soybean is self-pollinating plant, but crosspollina- tion may still occur at a low percentage (average $1.8 \%$ ) [27] under natural conditions, it is still not enough investigations to say whether the percentage of crosspollination can increase after mutagenic treatment, but we can assume that it can be possible. Whatever the cause of the observed variation is, breeders found and selected lines, which varied at MS-loci, linked with genes that control photoperiod sensitivity.

Five alleles were detected at the Satt100 locus in the mutant lines and parental cultivars and an additional allele for cultivar Ros' that was used as control. In comparison with the control varieties we identified dominant and recessive alleles of $E 7$ gene according to alleles of Satt100 locus. Three alleles were revealed for the Satt319 locus. According to our results cultivar Oksana, mutant lines Oksana M12 and Femida M29, which have a $167 \mathrm{bp}$ amplification fragment at locus Satt100 and a $175 \mathrm{bp}$ amplification fragment at locus Satt319, have the dominant allele of E7 gene. Genotypes Vilana and Harosoy OT 89-5 were used as the control, they have the same alleles (167 bp at Satt100 and 175 bp at Satt319 loci). We should mention that according to Molnar et al. [16], alleles $167 \mathrm{bp}$ at Satt100 and $175 \mathrm{bp}$ at Satt319 are associated with the dominant allele of $E 7$ gene.

In our investigation an allele of $175 \mathrm{bp}$ at Satt319 locus was detected in Femida, Femida M32, Podils'ka 416, Podilska 416 M40, but there was no confirmation of the presence of the dominant E7 al- 
lele, when we analyzed the Satt100 locus for these lines.

The presence of E3 dominant allele was established for Podils'ka 416, because for this cultivar we identified an amplification fragment of $215 \mathrm{bp}$ at locus Satt229, the same as we showed to be present in the control cultivar Maple Arrow - a carrier of the dominant $E 3$ gene. We did not detect any dominant alleles for E2 among investigated parental and mutant genotypes. The control allele for E2 - fragment of 243 bp at locus Sat_038 was found only in cultivar Ros', which is the carrier of $E 2$.
One of the purposes of soybean breeding in Ukraine is creation of ultra-early cultivars with high yield potential in order to originate a cost-effective cultivar, which produce high harvest as early as possible and permit, to prepare a field for sowing winter crops. For the creation of such genotypes, according to Dr. S.V. Ivanyuk, it is necessary to combine the recessive alleles $e 1, e 2, e 3, e 4, e 5, e 7$ in one genotype of new cultivar by crossing different donor sources of soybean. Golovenko et al. [28] stated on the basis of their research with the 7 alleles, that a recessive genotype for all these genes contributed to higher soybean yields in Belarus. Miladinovich et al. [29] have shown that the combina-

Table 2. Mean values of traits for different lines for three years of studies

\begin{tabular}{l|c|c|c|c|c}
\hline \multicolumn{1}{c|}{$\begin{array}{c}\text { Parental cultivars/ } \\
\text { mutant lines }\end{array}$} & DTF (days) * & DTM (days) ** & LV (days) & S-F(days) & Yield (t/ha) \\
\hline Oksana & 37.3 & 62.0 & 149.0 & 44.0 & 2.24 \\
Oksana M2 & 44.0 & 47.7 & 134.0 & 52.3 & 2.82 \\
Oksana M12 & 48.3 & 44.7 & 131.0 & 56.7 & 2.84 \\
Oksana M13 & 48.0 & 44.7 & 131.0 & 56.3 & 2.75 \\
Zolotysta & 27.7 & 34.0 & 121.0 & 34.3 & 2.24 \\
Zolotysta M16 & 28.7 & 39.7 & 126.0 & 37.0 & 2.54 \\
Zolotysta M20 & 39.0 & 41.3 & 128.0 & 47.3 & 2.00 \\
Femida & 26.7 & 42.3 & 129.0 & 33.3 & 2.52 \\
Femida M29 & 42.3 & 55.0 & 141.0 & 50.7 & 2.76 \\
Femida M32 & 36.3 & 51.0 & 137.0 & 44.7 & 2.46 \\
Podils'ka 416 & 35.3 & 44.3 & 131.0 & 42.0 & 2.58 \\
Podils'ka 416 M33 & 43.0 & 47.7 & 134.0 & 51.3 & 2.45 \\
Podils'ka 416 M38 & 43.7 & 45.0 & 131.0 & 52.0 & 2.50 \\
Podils'ka 416 M40 & 35.7 & 37.7 & 124.0 & 44.0 & 2.52 \\
Vilana & 39.3 & 57.7 & 144.0 & 46.0 & - \\
Maple Arrow $_{\text {LSD }_{0,05}}^{35.3}$ & 38.7 & 125.0 & 42.0 & - \\
LSD $_{0,01}$ & - & 11.31 & 12.52 & - & - \\
\hline
\end{tabular}

Notes: *- for DTF days from the beginning of June, ** - for DTM days from the beginning of August.

Table 3. Data of dispersion analysis of trait variations

\begin{tabular}{l|c|c|c|c|c|c|c|c}
\hline \multirow{2}{*}{ MS-loci/Trait } & \multicolumn{7}{|c}{ Variation source, MS } \\
\cline { 2 - 9 } & $\mathrm{DTF}$ & $\mathrm{Rd}^{\text {DTF }}$ & $\mathrm{DTM}$ & $\mathrm{Rd}^{\mathrm{DTM}}$ & $\mathrm{LV}$ & $\mathrm{Rd}^{\mathrm{LV}}$ & $\mathrm{S}-\mathrm{F}$ & $\mathrm{Rd}^{\mathrm{S}-\mathrm{F}}$ \\
\hline Satt100 $(\mathrm{df}=4)$ & 214.81 & 103.15 & $349.3 * * *$ & 62.0 & $350.1 * *$ & 70.2 & $243.9 *$ & 93.6 \\
Satt229 $(\mathrm{df}=3)$ & 126.94 & 111.68 & 53.1 & 88.8 & 48.6 & 97.1 & 137.8 & 104.3 \\
Satt319 $(\mathrm{df}=2)$ & 183.78 & 109.49 & $334.1 *$ & 75.5 & $336.6 *$ & 83.2 & 212.7 & 101.7 \\
Satt354 (df=3) & 256.99 & 102.81 & $275.0 *$ & 73.6 & $274.5 *$ & 81.7 & 263.8 & 95.7 \\
Satt365 (df =2) & 163.71 & 110.38 & 153.1 & 83.5 & 151.8 & 91.4 & 158.1 & 104.1 \\
Sat_038 (df=1) & $500.00 *$ & 104.23 & 74.8 & 86.7 & 66.6 & 94.6 & $586.8 *$ & 96.0 \\
\hline
\end{tabular}

Notes: $\mathrm{Rd}-$ Remaining dispersion; * Significant at $\mathrm{p}=0.05, * * \mathrm{p}=0.01$ and $* * * \mathrm{p}=0.001$. df - degree of freedom. 

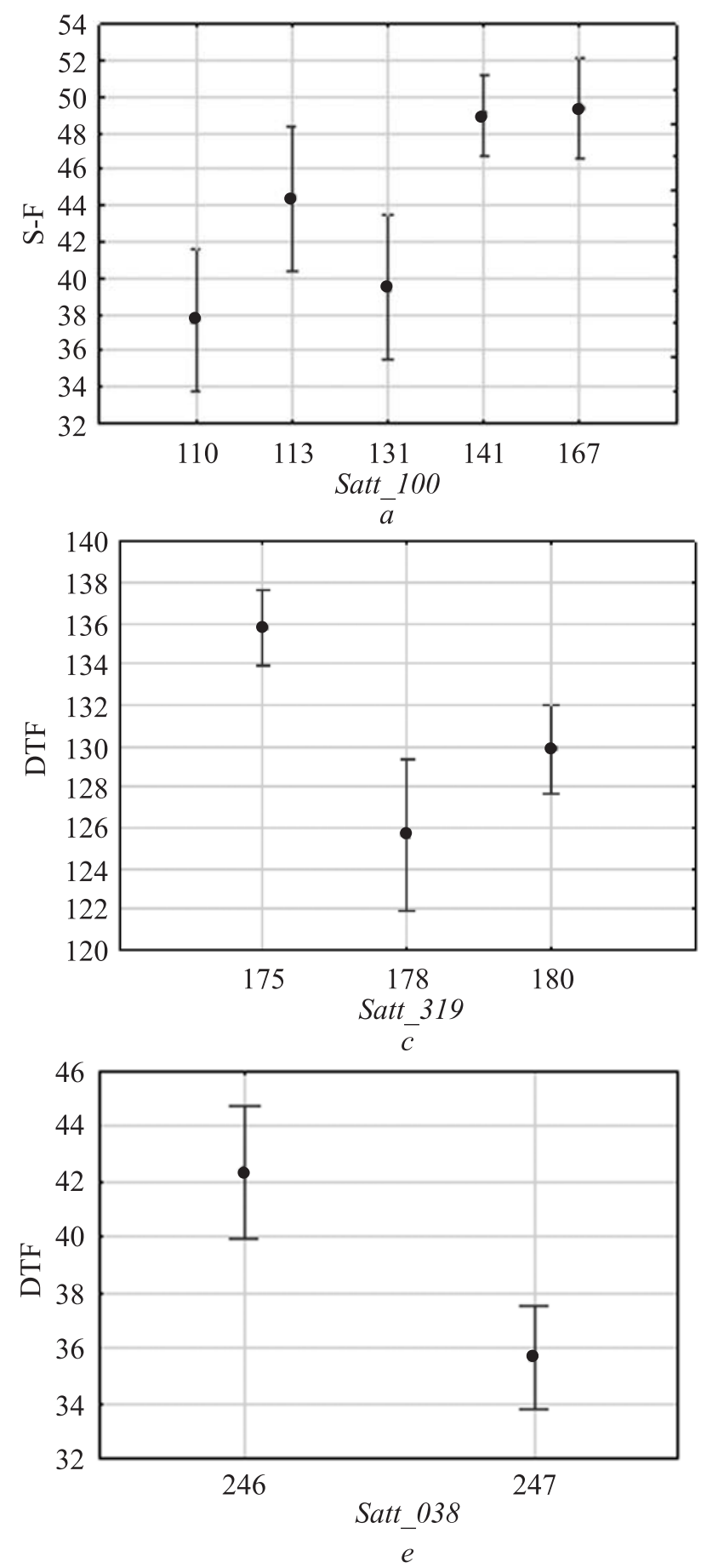
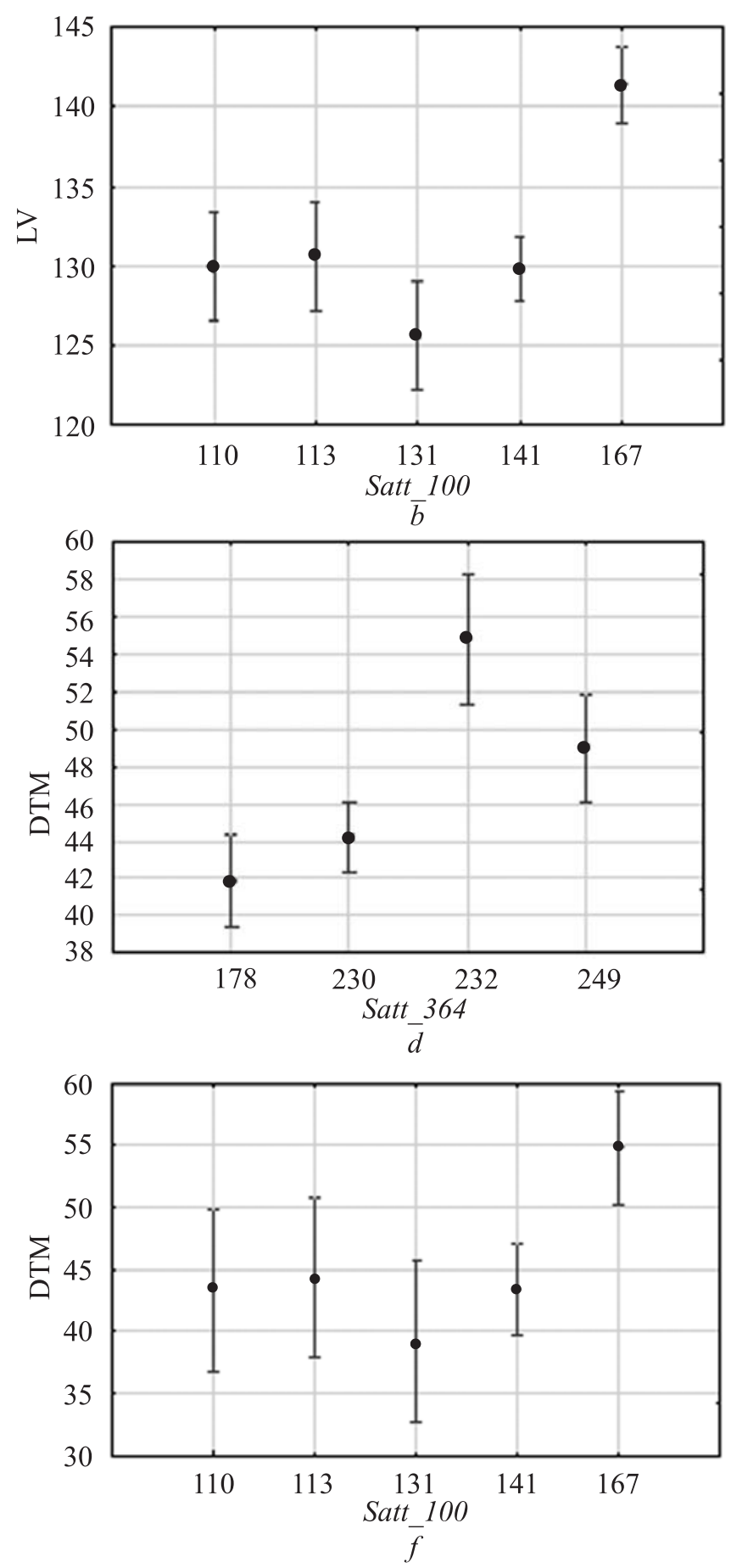

Fig. 2. Mean values of traits (vertical axis), depending on the presence of alleles of MS-loci. Bar $=$ std. error

tion of alleles e1-as/e2/E3/E4 was the most common for high yielding soybean genotypes in Novi Sad. They stated that this specific allele combination possibly is the optimal one for the climatic zone of CentralEastern Europe.

In our experiment E1 dominant allele has been detected in Zolotysta M 16, because this line has a $270 \mathrm{bp}$ allele at locus Satt365, the same allele was present in the control cultivars Cormoran AC and Ros' in which dominant $E 1$ is present.

Significant differences between investigated lines were detected in three years field trials for traits DTM (Fig. 1, a) and LV (Table 2).

There were no significant differences in the date of flowering, period shoots - flowering and yield (Table 2 , Fig. $1, b$ ) between all investigated genotypes.

AGRICULTURAL SCIENCE AND PRACTICE Vol. 6 No. 32019 

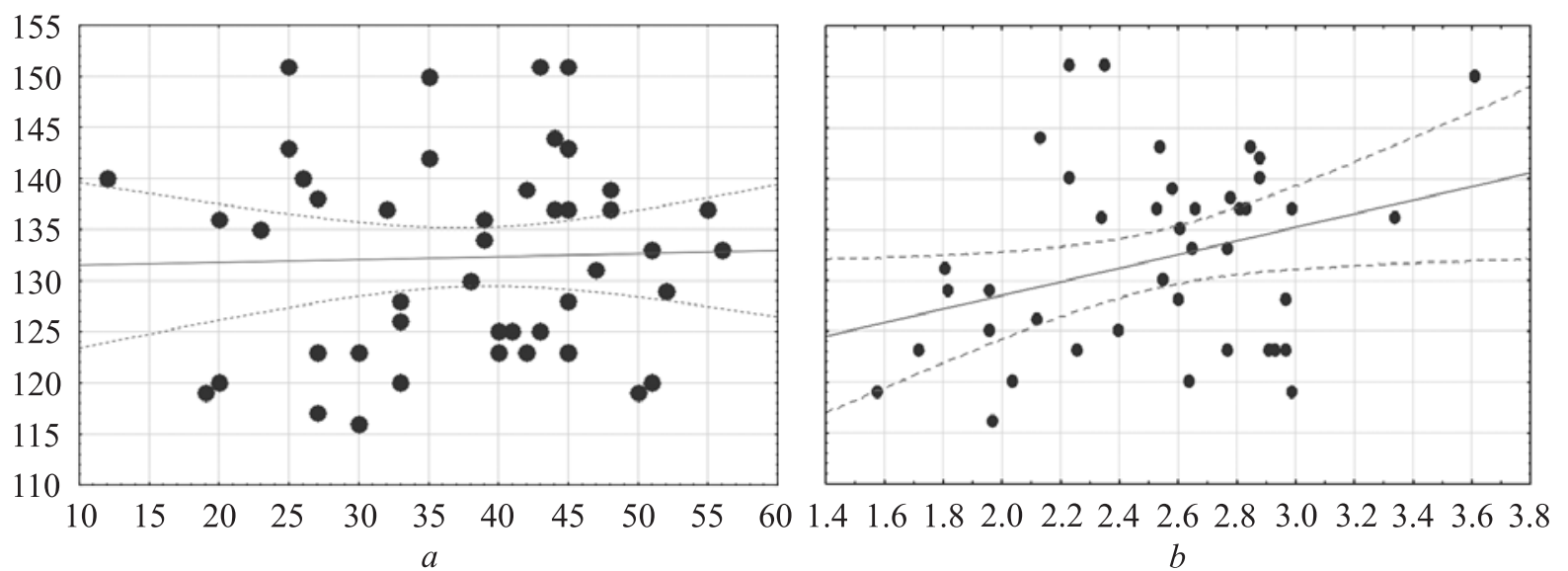

Fig. 3. Correlation between traits: (a) DTF (horizontal axis) and LV (vertical axis) $\mathrm{r}=0,03$; (b) Yield (horizontal axis) and LV (vertical axis) $(r=0,32 ; \mathrm{p}=0,05)$

According to the one-way dispersion analysis, alleles of MS-loci Satt229 and Satt365 have not affected investigated traits (Table 3).

On the other hand, alleles of MS-locus Satt100 affected all traits except DTF; alleles of Satt319 and Satt354 MS-loci affected DTM and LV; and alleles of Sat_038 MS-locus affected DTF and S-F.

Lines with alleles $167 \mathrm{bp}$ at Satt100 and 175 bp at Satt319 loci (that marks E7) were shown to have a longer vegetation period and later maturity than other ones. There were no significant differences in DTF for these lines.

There was no significant correlation between traits DTF and LV for all material studied $(r=0,03)$ (Fig. 3), between yield and DTM $(\mathrm{r}=0,03)$, and yield and DTF $(r=-0,22)$. Between yield and LV $(r=0,32)$ was significant correlation $(p=0,05)$. Thus, a longer growing season leads to a higher yield under Ukrainian growing conditions. Under Belarus growing conditions dominant allele $E 7$ delayed flowering of soybean plants for 4-5 days [22].

According to Molnar et al. [16] MS-marker Satt354 can be used to detect alleles of $E 4$; the dominant allele of $E 4$ is marked by a $251 \mathrm{bp}$ amplification fragment. According to personal communication of Dr. E.A. Aksyonova (Institute of Genetics and Cytology, Minsk) the amplification fragment for Vilana has smaller molecular size, than that of the control line L64-4830 with the dominant allele. In our investigation all amplification fragments sizes were smaller than those of cultivar Vilana. Thus, we can conclude that lines with dominant allele $E 4$ were not present in our experiment. The mutant lines with allele 232 bp at Satt354 locus reached maturity later than lines with other alleles at this locus
(Fig. 2). In literature, there is, however, no information that a $232 \mathrm{bp}$ fragment marks the dominant allele of $E 4$.

The lines with allele 247 bp at the Sat 038 locus flowered earlier than the lines with a $245 \mathrm{bp}$ allele in our field experiment.

Genotypes with the same alleles for each of the mentioned $E$-genes were grouped together. Dominant E1 allele, which is present in Zolotysta M16, could be involved in earlier flowering (about 10 days), than the other lines and cultivars demonstrated and the S-F period was 10 days shorter for this line in comparison with all investigated material. But of course, these shorter periods could also be caused/influenced additionally by interaction of the genotype by $E$-genes with environmental conditions and genetic background of cultivars.

We did not observe significant $E 3$ effects on the investigated agronomical traits.

Alleles of the E7-gene significantly influenced on the DTF, DTM, LV and S-F. Genotypes with the dominant allele were characterized by a longer DTF, DTM and LV. Genotypes with $E 7$ and $e 7$ alleles had not significant differences in the duration of S-F period, but for the lines with an allele 175 bp at locus Satt319 the characteristics S-F was shorter for 9 or 6 days for $E 7$ dominant and $e 7$ recessive alleles respectively. Furthermore, for lines with $e 7$ and an allele of $175 \mathrm{bp}$ at locus Satt319 there were no differences in the traits for LV and DTM and for soybean genotypes with the $E 7$ allele the maturity was later and LV was longer for 10 days.

Both groups with E1 and E3 dominant alleles contained only one genotype each. According to our results of MS analysis we predicted E1 to be present in 
Zolotysta M16 and E3 in Podils'ka 416. Presumably, lines created on the basis of one cultivar had smaller differences than those created on the basis of another cultivar. Perhaps in this case, it will be possible to determine the influence of the genotype on the DTF, DTM, LV, S-F and yield, which is also of importance.

Inside a group created from one ancestral genotype, for example, the group created on the base of Podils'ka 416 (included Podils'ka 416, Podils'ka 416 M33, Podils'ka 416 M38, Podils'ka 416 M40) we have not detected significant effects of the $E 3$ on the investigated traits. The same situation was with $E 1$ in the group produced on the base of cultivar Zolotysta. Inside the group of genotypes created on the base of cultivar Oksana dominant $E 7$ allele significantly decreased yield and did not significantly affect other traits. Also we observed difference in yield between both genotypes with E7 Oksana and Oksana M12.

It should be noted that in our three year field experiment cultivar Zolotysta, which belongs to maturity group 00, was earlier among the genotypes tested but its mutant lines have a tendency to be later. Oksana was the latest genotype, which we included to maturity group I. This cultivar has mutant derivates with a shorter LV on 18 days. For cultivar Zolotysta the length of the vegetative period was shorter for 28 days (almost 1 month) as compared to that of Oksana.

\section{CONCLUSIONS}

Our results show that the mutagens D-6, DMSSO-11, DMSSO-12, DMSNPIR-11, DUDMS12, D12DMC$11 \mathrm{~B}$ induced changes in soybean genome. By using these mutagens, it is possible to effectively increase genetic diversity in loci associated with the genes that determined photoperiod sensitivity of soybean. The obtained mutant lines could be involved in the breeding of soybean cultivars with different levels of photoperiodic sensitivity, terms of maturity, length of vegetation period and therefore adaptation ability. For example, mutant lines created on the basis of variety Oksana have significantly shorter LV $(\mathrm{P}=0.05$ and $\mathrm{P}=0.01)$ for about 15-18 days than Oksana because of the earlier maturity. Line Femida M29 reached maturity significantly later $(\mathrm{P}=0.05)$ then parental cultivar Femida.

The three year observations of the 10 mutant lines, parental cultivars and controls obtained under field conditions of the Vinnitsa region of Ukraine permit to make the following conclusion: the duration of the shootsflowering (S-F) period for soybean lines with $E 7$ and $e 7$ alleles differed not significantly, but the lines with an allele of $175 \mathrm{bp}$ at locus Satt319 the S-F period was 6-9 days shorter. Lines with $e 7$ and an allele of $175 \mathrm{bp}$ at locus Satt319, however, did not show differences in LV and DTM. For soybean genotypes with the E7 allele the DTF was longer for 3-9 days and LV for 10-11 days. We can conclude, that the changes in DTF and LV, which we have detected for mutant lines in comparison with parental cultivars, are on the measure of variation in MG groups and between the MGs, when we compared with the studies Liu et al. [25], but if the IFAP's soybean mutant lines is grown in other ecological condition the differences in DTM can became significant. In general, mutant lines that have been developed in the IFAP are interesting not only for breeding process, but also for investigation of molecular mechanism of changes in the soybean genome that permit to create lines with different times of maturity and LV.

These findings demonstrate again that under Ukrainian growing conditions the microsatellite loci studied, can be useful tools for marker assisted breeding of soybean cultivars with programmed terms of development in order to widen its cultivation range as much as possible. As noted by Rosenzweig et al. [30] and Miroshnichenko et al. [31], the most prominent for this target is the dominant $E 7$ allele, which did not affect the flowering time in comparison with recessive allele, although in our hands it had an extended reproductive stage that is preferable for soybean varieties. But in our experiments we obtained data that $E 7$ decrease yield inside the group of genotypes created on the basis of cultivar Oksana, but there are diffe-rences between lines with the same $E 7$ genotype, that is why research should be continued on more special genetic material, for example, near-isogenic lines or analogue lines.

\section{ACKNOWLEDGMENTS}

This study was funded by Ministry of Education and Science of Ukraine as research project 0117 U001114 «Polymorphism of wheat and soybean photoperiod sensitivity loci and plant development dependence on their allelic composition according to PCR analysis».

The authors declare that they have no conflict of interest.

The authors declare that this study complies with the current laws of the countries in which the experiments were performed.

\section{Поліморфізм за SSR-локусами асоційованими з генами $\boldsymbol{E}$ у перспективних для селекції мутантних ліній сої}


Д. О. Жарікова ${ }^{1}$, Г. О. Чеботар ${ }^{1}$, Є. А. Аксьонова ${ }^{2}$, I. В. Темченко ${ }^{3}$, С. В. Чеботар ${ }^{1 *}$

${ }^{1}$ Кафедра генетики та молекулярної біології, Одеського національного університету

ім. І.І. Мечникова, Одеса, Україна

2 Лабораторія цитоплазматичного успадкування, Інститут генетики і цитології, Мінськ, Білорусь

${ }^{3}$ Інститут кормів та сільського господарства Поділля НААН, Вінниця, Україна

e-mail: s.v.chebotar@onu.edu.ua*, gchebotar@gmail.com, fri@mail.vinnica.ua, axenova_elena@mail.ru, daria.bigen14@gmail.com

Мета. Аналіз генетичної різноманітності 10 ліній сої, створених шляхом хімічного мутагенезу за допомогою мутагенів: Д-6, ДМССО-11, ДМССО-12, ДМСНПІР-11, ДУДСМ-12, Д12ДМЦ-11Б на основі сортів Феміда, Оксана, Подільська 416, Золотиста були використані мікросателітні (МC) маркери: Satt100, Satt229, Satt319, Satt354, Satt365, Sat_038. Ці маркери зчеплені з генами, які визначають чутливість рослин сої до фотоперіоду та час дозрівання. В роботі використовували методи екстракції ДНК, ПЛР, МС-аналізу, проводили польовий експеримент, за допомогою дисперсійного аналізу обраховували отримані данні. Результати. Батьківські, мутантні лінії та контрольні генотипи охарактеризовано за алелями мікросателітних локусів, у дослідженому матеріалі виявлено 25 алелів за 6 мікросателітними локусами. Виявлені достовірні відмінності між дослідженими лініями за три роки польових випробувань за ознаками - час дозрівання та тривалість вегетаційного періоду. Виявлено вплив фактора «Алелі МС-локуса»: алелі Satt100 мали ефекти на всі ознаки, крім DTF (кількість днів до цвітіння); алелі Satt319 і Satt354 впливали на DTM (кількість днів до дозрівання) та LV (тривалість вегетаційного періоду); алелі Sat_038 мали вплив на DTF i S-F (тривалість періоду від сходів до цвітіння). Лінії з алелями 167 п.н. за Satt100 та 175 п.н. за Satt319 локусами (що маркують домінантний стан гену E7) мали більш тривалий вегетаційний період та більш пізніше дозрівання, ніж інші. Лінії 3 алелем 247 п.н. за Sat_038 зацвітали раніше, ніж лінії з алелем 245 п.н., а лінії з алелем 232 п.н. за Satt354 досягали зрілості пізніше, ніж лінії з іншими алелями цього локусу. Висновки. Нами виявлено, що застосовані мутагени індукували зміни в геномі сої і за допомогою цих мутагенів можна ефективно збільшувати генетичне різноманіття сої за локусами, пов'язаними 3 генами/ локусами, що визначають час дозрівання та/ або фотоперіодичну чутливість, що робить можливим створення сортів сої з різними термінами дозрівання та урожайністю. Мікросателітні маркери, зокрема Sat_038, Satt100, Satt319 і Satt354, можуть бути корисним інструментом в маркер-опосередкованій селекції сортів coї із запрограмованими темпами розвитку. Ми не спостерігали достовірного впливу «Алелів МС-локусу Satt229», який, як відомо, зчеплений з E3, на досліджувані агрономічні ознаки. Для генотипів сої з алелем $E 7$ кількість днів до колосіння була більшою на 3-9 днів, а довжина вегетаційного періоду на 10-11 днів. У ліній 3 алелем 175 п.н. в локусі Satt319 період сході-цвітіння був коротший на 6-9 днів.

Ключові слова: соя, мутантні лінії, SSR-локуси, мікросателітні маркери, $E$ гени, фотоперіод, строки дозрівання.

\section{Полиморфизм по SSR-локусам ассоциированным с генами $E$ в перспективных для селекции мутантных линиях сои}

Д. А. Жарикова ${ }^{1}$, Г. А. Чеботарь ${ }^{1}$, Е. А. Аксенова ${ }^{2}$, И. В. Темченко ${ }^{3}$, С. В. Чеботарь ${ }^{1}$ *

${ }^{1}$ Кафедра генетики и молекулярной биологии, Одесского национального университета им. И.И. Мечникова, Одесса, Украина

2 Лаборатория цитоплазматического наследования, Институт генетики и цитологии, Минск, Беларусь ${ }^{3}$ Институт кормов и сельского хозяйства Подолья НААН, Винница, Украина

e-mail: s.v.chebotar@onu.edu.ua*, gchebotar@gmail.com,fri@mail.vinnica.ua, axenova_elena@mail.ru, daria.bigen14@gmail.com

Цель. Анализ генетического разнообразия 10 линий сои, созданных путем химического мутагенеза с помощью мутагенов: Д-6, ДМСС-11, ДМСС-12, ДМСНПИР-11, ДУДСМ-12, Д12ДМЦ-11Б на основе сортов Фемида, Оксана, Подольская 416, Золотистая с использованием микросателлитных (МC) маркеров: Satt100, Satt229, Satt319, Satt354, Satt365, Sat_038, сцепленных с генами, которые определяют чувствительность растений сои к фотопериоду и определяют сроки созревания. В работе использованы методы - экстракции ДНК, ПЦР, МСанализа, полевого эксперимента, дисперсионного анализа (ANOVA) для обсчета полученных данных. Результаты. Родительские сорта, мутантные линии и контрольные генотипы охарактеризованы по аллелям микросателлитных локусов, выявлено 25 аллелей по 6 микросателлитным локусам. Выявлены достоверные различия между исследуемыми линиями за три года полевых испытаний по признакам - время созревания и продолжительность вегетационного периода. Установлено влияние факторов «Аллели МС-локусов» на исследуемые признаки, так аллели Satt100 оказывали влияние на все признаки, кроме DTF (дни до цветения); Satt319 и Satt354 влияли на DTM (на количество дней до созревания) и LV (на продолжительность вегетационного периода); аллели Sat_038 влияли на DTF и S-F (на продолжительность периода всходы-цветение). Линии с аллелями 167 п.н. по Satt100 и 175 п.н. по Satt319 локусам (маркирующим доминантный ген E7), имели 
более длительный вегетационный период и созревали позднее, чем другие. Линии с аллелем 247 п.н. по локусу Sat_038 зацветали раньше, чем линии с аллелем 245 п.н., а линии с аллелем 232 п.н. по Satt354 достигали зрелости позже, чем линии с другими аллелями по этому локусу. Выводы. Нами выявлено, что примененные мутагены индуцировали изменения в геноме сои и с помощью этих мутагенов можно эффективно увеличивать генетическое разнообразие сои по локусам, связанным с генами / локусами, определяющими сроки созревания и/ или фотопериодическую чувствительность, что делает возможным создание сортов сои с разными сроками созревания и урожайностью. Микросателлитные маркеры, а именно Sat_038, Satt100, Satt319 і Satt354, могут быть полезным инструментом в маркер-опосредованной селекции сортов сои с запрограммированными темпами развития. Мы не детектировали достоверного влияния «Аллелей MC-локуса Satt229», который, как известно, сцеплен с $E 3$, на исследуемые агрономические признаки. Для генотипов, у которых детектирован E7, количество дней до колошения было больше на 3-9 дней, а продолжительность вегетационного периода на 10-11 дней. У линий с аллелем 175 п.н. по локусу Satt319 период всходы-цветение был короче на 6-9 дней.

Ключевые слова: соя, мутантные линии, SSR-локусы, микросателлитные маркеры, $E$ гены, фотопериод, сроки созревания.

\section{REFERENCES}

1. Bernard RL. Two major genes for time of flowering and maturity in soybeans. Crop Sci., 1971;11(2):242-4. doi:10.2135/cropsci1971.0011183X001100020022x.

2. Dissanayaka A, Tito OR, Shaokang DYF, Githiri SM, Rodas FR, Abe J, Takahashi R. Quantitative trait locus mapping of soybean maturity gene E5. Breed. Sci. 2016;66(3):407-15. doi:10.1270/jsbbs. 15160.

3. Watanabe S, Harada K, Abe J. Genetic and molecular bases of photoperiod responses of flowering in soybean. Breed. Sci., 2012;61(5):531-43. doi:10.1270/ jsbbs.61.531.

4. Ivanyuk S. Suchasna selektciya soi. Agrobisnes siogodni. 2014;17(288):14-20. http://agro-business.com.ua/agro/ ahronomiia-sohodni/item/487-suchasna-selektsiia-soi. html (in Ukrainian).

5. Chekalin NM, Tyshchenko VN, Batashova EM. Selektciya i genetyka okremyx kul'tur. Poltava, FOP Hovorov SV, 2008;244-58. https://agromage.com/stat_id.php?id=487. (in Ukrainian).

6. Berbenets $O$. World-wide production of soya as an inexhaustible source of vegetable proteins and Ukraine's place in the global trading market. Agrosvit, 2019;10:415 (in Ukrainian). doi: 10.32702/2306-6792.2019.10.41.

7. Zharikova D, Ivanyuk $S$, Chebotar $G$, Korniychuk $O$, Chebotar S. Polymorphism of soybean cultivars and breeding lines revealed by marker Satt100 associated with the $E 7$ locus. Breeding Grasses and Protein Crops in the Era of Genomics, 2018;267:220-5. doi: 10.1007/9783-319-89578-9_40.

8. Prysiazhniuk L, Shytikova Y, Dihtyar O, Mizerna N. Evaluation of genetic and morphological distances between soybean (Glycine $\max$ L.) cultivars. Zemdirbyste-Agriculture, 2019;106(2):117-22. doi: 10.13080/z-a.2019. 106.015 .

9. Prysiazhniuk L, Melnyk S, Shytikova Y, Sihalova I, Ivanitskaya A. Application of SSR markers to differentiate new varieties of soybean (Glycine Max (L.) Merr.). Plant Varieties Studying and protection, 2017;13(3):269-76 (in Ukrainian). doi: https://doi.org/10.21498/2518-1017. 13.3.2017.110709.

10. Volkova NE, Mizerna NA. Soybean cultivars (Glycine Max (L.) Merr.) typing for Satt100 microsatellite marker of E7 gene of photoperiod sensitivity. Plant varieties studying and protection, 2017;13(4):373-8 (in Ukrainian). doi: https://doi.org/10.21498/2518-017.13.4.2017.117740.

11. Zharikova DO, Aksyonova EA, Chebotar GO, Chebotar $S V$. Usage of microsatellite loci linked with $E$ genes, for identification and passportization of soybean varieties. [Vykorystannya mikrosatelitnyx locusiv, zcheplenyx z genamy $E$, dlya identyfikacii ta pasportyzacii sortiv soi]. Factors in experimental evolution of organisms. 2019;24: 80-5. (in Ukrainian). Available at: http://utgis.org.ua/ journals/index. php/Faktory/article/view/1083.

12. Vasilchenko MS, Avksentyeva OA, Zhmurko VV. Photoperiodic response and callus formation of the isogenic $E$-genes soybean lines. J. V.N. Karazin Kharkiv Nat. Unty, Series: biology, 2014;29(1129):44-52 (in Ukrainian).

13. Babych AA, Ivanyuk SV, Vilgota NV. Influence of chemical mutagens on the productivity elements of soybean plants. Feeds and Feed Production. 2013;(77):3-8 (in Ukrainian).

14. Vilgota $N V$. Vplyv khimichnyh mutageniv na minlyvist' oznak roslyn soi. First Inter. Sci. Conf. «State and prospects of forming high-quality plant resources in Ukraine». 2012; p.p. 54-5. http://confer.uiesr.sops.gov. ua/ kiev2012/paper/viewFile/9617/4445.

15. Rjabuha SS, Chernyshenko PV, Sjerikova LG. Efektyvnist' zastosuvannya kchimichnykch mutageniv v selekcii soi. Plant breeding and seed production. 2012;(102):60-5 (in Ukrainian). https://doi.org/10.30835/2413-7510.2012. 59821.

16. Molnar SJ, Rai S, Charette M, Cober ER. Simple sequence repeat (SSR) markers linked to E1,E3, E4, and E7 maturity genes in soybean. Genome. 2003;46(6):102436. doi: $10.1139 / \mathrm{g} 03-079$.

17. Rosenzweig VE., Aksyonova EA, Milash SB, Goloenko $D V$, Davydenko $O G$. Prospects of exploiting of photoperiod sensitivity gene $E 7$ in early soybean breeding and revealing of its sources with SSR-markers. Soybean Genetics Newsletter. 2008;35:1-7.

18. Ukrainian Institute for plant cultivar examination. Available at: http://service.ukragroexpert.com.ua. 


\section{POLYMORPHISMS IN SSR-LOCI ASSOCIATED WITH E GENES IN SOYBEAN MUTANT}

19. State register of plant varieties suitable for dissemination in Ukraine in 2019. Kyiv. 2019. Available at: https://sops. gov.ua/reestr-sortiv-roslin [Date accessed: 23 Jun. 2019].

20. Babych AA, Ivanyuk SV, Vilgota $M V$. Effect of chemical mutagens on survival of soybean plants. Feeds and Feed Production. 2012;(73):15-20 (in Ukrainian).

21. Vasko VO, Gudym OV, Rozhak OG. Application of experimental mutagenesis in plant breeding. Plant Breeding and Seed Production, 2015;107:8-18. (in Ukrainian). doi. org/10.30835/2413-7510.2015.54025.

22. Davydenko OG, Golovenko DV, Rosenzweig VE. Approaches to selection of early ripening soybean varieties. [Podhody k selekcii rannespelyx sortov soi]. Results of research soybean during the years of reforming and the direction SIWR for 2005-2010: sat. articles of the meeting. Krasnodar, 2004:110-27.

23. Shurtleff W, Aoyagi A. Early named soybean varieties in the United States and Canada. California, USA, Soyinfo Center. 2013:961.

24. Catalog of varieties of forage and field crop breeding. Vinnitcia, Ukraine. IFAP, 2014; 20 (in Ukrainian). Available at: http://fri.vin.ua/download_ materials/catalog soya_2014.pdf.pdf.

25.Liu X, Wu Ji-An, Re H, Qi Y, Li C, Cao J, Zhang X, Zhang Z, Cai Z, Gai J. Genetic variation of world soybean maturity date and geographic distribution of maturity groups. Breeding Science 2017;67(3):221-32. doi:10.1270/jsbbs. 16167.

26. Zharikova DO, Chebotar GO, Vilgota MV, Temchenko IV, Chebotar $S V$. Characteristics of mutant soybean lines at Satt100 and Satt319 loci linked with E7 gene. Factors in experimental evolution of organisms. 2018;23:52-6 (in Ukrainian).

27. Ray JD, Kilen TC, Abel CA, Paris RC. Soybean natural cross-pollination rates under field conditions. Environmental biosafety research. 2003;2(2): 133-8. doi: 10.1051/ebr:2003005.

28. Golovenko DV, Rosenzweig VE, Milash SB, Aksyonova
EA, Davydenko OG. Application of photoperiod sensitivity genes for soybean breeding in Belarus. Abstract of Conference «Control of Flowering Time and Applications for Plant Breeding» Salzau, Germany. 2008:60 1. [in English]

29. Miladinović J, Ćeran M, Đorđević V, Balešević-Tubić S, Petrović K, Đukić V, Miladinović D. Allelic variation and distribution of the major maturity genes in different soybean collections. Front Plant Sci. 2018;9:1286. doi: 10.3389/fpls.2018.01286.

30. Rosenzweig VE, Goloenko DV, Davydenko OG, Shablinskaya $O V$. Breeding strategies for early soybeans in Belarus. Plant Breeding, 2003;122(5):456-8. doi: 10.1046/j.1439-0523.2003.00874.x.

31. Miroshnichenko MV. Changes in agronomic traits caused by breeding in soybean. [Izmenenie khozyaistvennobiologicheskikh priznakov sortov soi $\mathrm{v}$ rezultate selektsii]. Ph.D. thesis, Krasnodar, 2005. [in Russian]. Available at: https://www.dissercat.com/ content/izmenenie-khozyaistvenno-biologicheskikh-priznakovsortov-soi-v-rezultate-selektsii.

\section{ABBREVIATIONS AND TERMS}

IFAP Institute of Feeds and Agriculture of Podillia of NAAS, Vinnitsa, Ukraine

SSR Simple sequence repeat

MS Microsatellite markers

MS-locus Microsatellite locus

DNA Deoxyribonucleic acid

PCR Polymerase chain reaction

DTF Days to flowering

DTM Days to maturation

LV Length of the vegetative period (days)

S-F Duration of the period shoots-flowering (days)

LSD Least significant difference

Rd Remaining dispersion

bp Base pair 